\title{
4.0 Industry: understanding the impact of technological changes of the fourth industrial revolution on competitiveness in sandal factories of Cariri Region
}

New technologies are increasingly appearing to assist people in all areas. In the footwear industry it would not be different, where the industry 4.0 or fourth industrial revolution characterizes the current moment. This research examined how the managers of some sandal factories in the Cariri Region are realizing the changes and technological advances of industry 4.0 as a source of competitive advantage. A field research of a basic nature, with a qualitative and descriptive approach, where interviews were applied with the managers of sandal factories in the Region of Cariri, chosen for convenience and judgment of the researcher. The study is relevant due to the existence of great changes that have been taking place within the companies along with new technologies that are emerging, but it is not known how managers receive these changes and use them to benefit the company and in the search for a differential for competitive advantage in the market. At the end of the research it was possible to conclude that from the reality of each manager and company the way they receive and use the technologies of the fourth industrial revolution changes, and the lack of knowledge, structure, and money in the smaller companies makes the potential use competitive advantage is not so much taken advantage of

\subsection{Indústria: entendendo o impacto das mudanças tecnológicas da quarta revolução industrial na competitividade das fábricas de sandálias da Região do Cariri}

\begin{abstract}
Novas tecnologias estão aparecendo cada vez mais para ajudar pessoas em todas as áreas. Na indústria de calçados não seria diferente, onde a indústria 4.0 ou a quarta revolução industrial caracteriza o momento atual. Esta pesquisa examinou como os gerentes de algumas fábricas de sandálias da região do Cariri estão percebendo as mudanças e os avanços tecnológicos da indústria 4.0 como fonte de vantagem competitiva. Pesquisa de campo de caráter básico, com abordagem qualitativa e descritiva, onde foram aplicadas entrevistas com os gerentes das fábricas de sandálias da Região do Cariri, escolhidos por conveniência e julgamento do pesquisador. $O$ estudo é relevante devido à existência de grandes mudanças que vêm ocorrendo nas empresas, juntamente com as novas tecnologias que estão surgindo, mas não se sabe como os gerentes recebem essas mudanças e as utilizam para beneficiar a empresa e na busca de uma solução. diferencial para vantagem competitiva no mercado. Ao final da pesquisa, foi possível concluir que, a partir da realidade de cada gerente e empresa, a maneira como eles recebem e usam as tecnologias da quarta revolução industrial muda, e a falta de conhecimento, estrutura e dinheiro nas empresas menores faz com que a vantagem competitiva do uso potencial não é tão aproveitada.
\end{abstract}

Palavras-chave: Indústria 4.0; Quarta Revolução Industrial; Vantagem competitiva.

Topic: Planejamento, Estratégia e Competitividade

Reviewed anonymously in the process of blind peer.

Alana Vitória Rodrigues Barreto

Centro Universitário Dr. Leão Sampaio, Brasil

http://lattes.cnpq.br/2279311028611096

alanabarreto45@hotmail.com

Antônio Wilson dos Santos

Centro Universitário Dr. Leão Sampaio, Brasil

http://lattes.cnpq.br/9085815217693327

wilson@fvs.edu.br

Antoniel dos Santos Gomes Filho

Faculdade Vale do Salgado, Brasil

http://lattes.cnpq.br/9563145614494252

http://orcid.org/0000-0003-2230-4315

antoniel.historiacomparada@gmail.com
Received: 04/01/2019

Approved: 04/03/2019
Referencing this:

BARRETO, A. V. R.; SANTOS, A. W.; GOMES FILHO, A. W.. 4.0 Industry: understanding the impact of technological changes of the fourth industrial revolution on competitiveness in sandal factories of Cariri Region. Revista Brasileira de Administração Científica, v.10, n.1, p.3142, 2019. DOI: http://doi.org/10.6008/CBPC2179-684X.2019.001.0003 


\section{INTRODCTION}

Nowadays the companies are feeling intensely the impacts caused by the arrival of the technological innovations, where their growth and development depend a lot on that to succeed in their actions. This evolution means that companies have to undergo transitions to be able to adapt to the new time and to maintain a highly competitive and growing market. In the footwear industry of our country would not be different, and especially in the sandal factories in the Cariri Region, which will be the aim of this research.

The fourth industrial revolution also known as 4.0 industry, according to Silveira (2016) "It is a recently proposed industry concept and that includes the main technological innovations in the fields of automation, control and information technology, applied to manufacturing processes". New technologies are emerging with great force in the current $21^{\text {st }}$ century, they facilitate the life of the human being in all areas, and most of the systems used in industries and companies in general are conducted by them.

So the arrival of these new technologies will bring about great changes, they can reduce or even do away with manual work in many sectors, making automated many of the processes, in the not too distant future what is expected is that industries become fully automated, with a minimum of human intervention to complete the production process.

Yes, there are advantages and disadvantages in this whole revolution in current industry, but it is not really known how they happen within organizations and how managers understand it and work to keep a balance, to bring all the benefits desired by the organization, where through the research we can better understand the true knowledge about how managers act in relation to all the problems based on the research in question. Howsoever the issue investigated by the survey was what is the knowledge level of managers of the sandal factories in the Cariri Region about this advent and the impacts of these changes on the competitiveness of companies.

The research aimed to analyze the level of knowledge of managers in the footwear sector of the Cariri Region about the technological changes of the 4.0 industry as a source of competitive advantage, and it is justified by the fact of the need for agility in processes and interconnection of systems to facilitate actions within companies, where at present all of them seek to fit into the constant evolution of things and the one that doesn't fit ends up being left behind, not answering to the market or to the needs of the company and its customers.

This is a field research, with a qualitative and descriptive approach, in which the scenario were 3 companies/factories from the footwear branch in the Region of Cariri Cearense, through interviews to their managers, chosen by the convenience and judgment of the researcher, because she herself judged that it would be necessary to better understanding the experience of technologies and managers, choosing a large, a medium and a small business, thus being able to better identify their actions according to their possibilities. 
4.0 Industry: understanding the impact of technological changes of the fourth industrial revolution on competitiveness in sandal factories of Cariri Region

\section{METHODOLOGY}

The research has logical bases of investigation in the inductive method, with databases obtained with previous bibliographic research, in scientific articles and books of relevance to the study. Held in three companies / factories in the footwear branch in the Cariri Region of Ceará, with its managers, where the researcher in question thought the three selected factories and their managers should be a large company, a medium and a small, thus being able to better characterize and identify the experience of the technologies in each of them, and the differences that can be found due to the possibilities of each.

Field research, multicases study through interviews, having qualitative and descriptive approach, which for Gerhardt et al. (2009) "the qualitative research is not concerned with numerical representation, but rather with the deepening of understanding of a social group, an organization, etc.", with exploratory objective. Semi Structured interview by guidelines, which for Vergara (2009), the interview can be informal or open, almost a conversation thrown away, focused only on the subject addressed by the research, or by agenda, which establish points to be followed and asked the interviewees.

The data collection was performed through the aid of a structured interview script, containing 14 (fourteen) questions, applied to managers who know the production area of three different sandal factories, located in the Cariri Region, where the interview was recorded on audio with transcription for better understanding the data and results obtained. The research was based on an analysis of the responses obtained in the interview (the subject's speech), which is a form of presentation of results of qualitative research. The aim was to explore and investigate the whole problem in question by seeking to clarify it.

\section{Data Analysis}

The first company which has been applied to an interview with the manager, who holds the position of production manager, was the small one, where the respondent only has high school education and is attending to a technical course in footwear, works at the same company for six years, same time of its existence. The interviewee was able to clarify that the company has about $30 \%$ of automation in its production, and on the automation in the company answered: "The automation that exists in the production can be identified through the matrix machines that produce the separate mold parts, requiring human intervention only to be turned on and to remove the leftover material at the end of each batch produced".

Agreeing thus with Ribeiro (1999) on his definition of automation. His understanding of the terms 4.0 industry / fourth industrial revolution is very superficial, being far from the definition of Morais et al. (2016), he merely characterized them as "the arrival of new technologies", as he didn't know much about the subject he couldn't answer the questions about the perceived changes in the company relative to the 4.0 industry, explained only about a program that exists in the company, "the program saves the data of customers and suppliers, their purchases historic, sale, etc., which for the company is a very significant technological advance; because of the arrival of machines that reduce manual labor and this data program, has increased 
4.0 Industry: understanding the impact of technological changes of the fourth industrial revolution on competitiveness in sandal factories of Cariri

efficiency in work stations and their productivity", which according to Borba et al. (2013) definition is not characterized as big data.

On the terms Internet of Things, big data and cyber physical system, the interviewee said "I know the big data" and related the term with the company's database system, being confused about what it really means big data, associating the use of the database as something that benefits the company, with valuable information, but which is not really related to the big data technology or to the 4.0 industry.

For him the great differential of the company that is used as competitive advantage is the quality of the final product, "we seek to manufacture the products as if they were for ourselves", and despite not having any technological innovation related to the 4.0 industry, he sees the quality of the final product as a competitive advantage against the competition, “we haven't yet used these technologies, but we can't avoid them from being deployed in the company in the future, and I see them as of great importance to stand out in the market compared to our competitors".

He explained that within its possibilities the company optimizes its processes to the maximum, 'we try to study the whole production process and reduce the failures every day, our intention is to use technologies in the future that will further improve product quality, the $3 \mathrm{~d}$ printer would be very good to be able to customize the product for the customer and decrease the manual work'. The second company which has been applied to an interview with the manager, who holds the position of administrative manager, was 'a medium-sized business', where the interviewee has a degree in business administration, and has worked in the company for ten years.

The respondent could clarify that the company has about $40 \%$ automation in its production; 'it's still pretty manual', he pointed out, about his understanding of the terms 4.0 industry / fourth industrial revolution, his description was further clarified: 'are the changes of methods and processes, the arrival of new technologies with great proximity to the automation of processes, where the company tries to follow on that side and adapt to fit these patterns of these changes, in the quest for achieving the 4.0 standard'; agreeing with Amorim (2017) definition on the subject.

About the changes perceived in the company in relation to the 4.0 industry, explained that it was perceived with the acquisition of automated machines, 'formerly in the machining center of the company we worked with a completely manual process, 14 employees were required to complete that process and today with the arrival of 7 automated machines only 6 employees are required to complete the same process', with this became very clear to him the optimization of production thanks to these changes, "we increased production efficiency by $80 \%$, we reduced the problems and increased the hits of the processes", Castro (2005) explains these events by talking about technological changes through evolution.

Even having a degree in business administration, when he was asked if he knew some terms: Internet of Things, big data and cyber physical system, he said he knew only the term Internet of Things, and clarified 'none of them are used in the factory's production system', according to him the company has its differential 
4.0 Industry: understanding the impact of technological changes of the fourth industrial revolution on competitiveness in sandal factories of Cariri

in front of the market in the search of competitive advantage that would be: 'the implanted technologies, the product's design, and constant search to follow the new trends of the market in which we operate'.

Although it does not have any technological innovation related to the 4.0 industry, he considers them of great importance for the growth of the company, 'over time the need for the deployment of technologies related to 4.0 industry will be required, and gradually these advances that have been taking place within the company, such as automated machines that streamline processes, and that for now still comply with the demand and makes our differential against the competition will evolve even more'.

When asked if he considers the company as a smart factory that optimizes its processes to the maximum, he explained 'the company has great potential in the market in which operates, but can evolve even more, soon we will be investing in one of the 4.0 industry technologies, the 3D printer, to improve the quality of our products, reduce manual labor and thus seek to take another step forward in relation to our competitors'. These trends brought by the advance of industry 4.0 and its inevitable need for implementation in the future that the interviewee describes in his last speeches, according to the vision of Rodrigues et al. (2016) will make factories smart, benefiting companies and increasing their quality and efficiency.

The third and last company which has been applied to an interview with the manager, who holds the position of supervisor of engineering and quality, was the big one, where the respondent has a degree in production engineering, MBA in quality management, is attending to a specialization course in work safety engineering and has worked in the same company for nine years and two months. When asked about the percentage degree of automation of the company the respondent answered: 'taking 4.0 industry as reference in 2017 the company is at level 2.0, where the goal is to reach level 4.0 until $2021,50 \%$ of the processes are still manual and $50 \%$ are automated, and in the last eight years many automation initiatives have happened'.

In relation to his understanding of the term 4.0 industry / fourth industrial revolution, his definition was very complete and truthful, having some similarities with the definition of Sugayama et al. (2016), 'Revolution of Cyber-Physical Systems, smart production that is premised on the connectivity between computational and physical elements to improve manufacturing performance'.

On the technological changes related to industry 4.0 that have been noticed since the interviewee entered the company, he explained: 'I have been in the company for nine years and had the privilege of experiencing many initiatives in the last 8 years, such as the implementation of: Matrix (PLM, Product Lifecycle); siMOn (production supervisors); 2D printing (automation connected to the production system); PreActor (APS for production); Automation, such as new solutions for EVA cutting and coverline for splitting EVA'.

It can then be said that with all these advances it was possible to notice great evolutions in its production, 'the company has invested more than 3 million reais (brazilian money) a year in automation and ergonomics, aiming to gain productivity and above all, comfort and safety for its employees. Today the main sectors are monitored in real time through SiMOn, which allows making agile decisions to correct loss of efficiency, either by performance, availability or quality. All products have their information registered and 
4.0 Industry: understanding the impact of technological changes of the fourth industrial revolution on competitiveness in sandal factories of Cariri

available, from the raw material required (item and quantity), to the manufacturing technique and production capacity of each operation'.

The respondent affirms to know the three terms that were cited: Internet of Things, big data and cyber physical system, however it has none directly applied to its production system, 'we're trying to apply throughout the system until 2021 , and this $1^{\text {st }}$ year of 4.0 journey will be dedicated to the PLM structuring (Product Lifecycle), to Digital Engineering and GCP (product cost management)'.

As differentials that the company uses in its production to stand out in the market and obtain competitive advantage, the interviewee reported that: "First of all for the company comes the people, in addition to the ergonomic aspects (such as investment in chairs and stands, ventilation, internal temperature, lighting) the company has invested heavily in education, knowledge will be its great competitive power'.

In continuity, '[...] It was inaugurated in October of this year the University of the Company, where people will have the privilege of learning transversal themes, from leadership and management, industrial techniques and business, it will develop new ways of thinking and acting, stimulate people and teams to improve always, considering processes, technologies and products, initiatives of continuous improvement of the company's excellence model, people from different hierarchical levels, from the production assistant to the manager, being trained and applying knowledge of lean manufacturing in the production processes [...]'.

Going on, '[...] Kaizen Events are being held monthly with focus on productivity 5.0 and implementation of the SMED methodology, which will allow change from the waste culture to focus on excellence, also offering training in multifunctionality, aimed at the audience of production helpers, where topics are dealt with from safe behavior, quality with market vision to the operational technique of our production processes(screen printing, EVA manufacturing, sewing, painting). The satisfaction of the company and the learning will allow to evolve, will lead to new levels, we recognize that the company is investing in us and this will be converted into competitive gains driven by innovation and organizational efficiency. In addition to all this, structural and technological investments have been made, dedicated to the pursuit of intelligent production and until 2021 the $4^{\text {th }}$ industrial revolution will be implanted'.

According to Mendes (2011), competences become skills and it can become a competitive advantage, but for this it's necessary to perform and to explore this differential. Thus, what was explained in the interviewee's previous speech characterizes a differential that the company seeks and explores to the maximum in order to obtain a competitive advantage in its market of operation.

According to the interviewee the technological innovations related to 4.0 industry that they are trying to implant in the company will be a differential against the competition, 'from the ability to accumulate data, simulate scenarios, transform information in real time or even in a predictive way, avoiding unexpected stops, which will allow productivity gains, optimize resource utilization, speed up deliveries, a wider range of custom products without the need to reconfigure production lines (quick setup); reduction of errors, energy savings and, thus, cost-cutting'. And when asked if considers the company a smart factory, that optimizes to 
the maximum its production, explained: 'as stated before, there is still much to be done, but the 4.0 industry has become a reality much closer to the company'.

It was asked which of the 4.0 industry technologies he thinks would be interesting to be deployed in the company to achieve some sort of competitive advantage, and he answered: the basis of the revolution is the digital pillar, but the infrastructure must be prepared to receive the electronics. Having the data and information and not being able to generate fast and autonomous decisions due to lack of infrastructure will not help, similarly, having infrastructure and not having a system that makes decisions will not be able to correct routes or predict behaviors. Until the end of the search for the total deployment of 4.0 industry in its processes, we intend to use four of them, which are: Big Date: necessary to extract immense amounts of data from a wide variety of sources, to process them in real time and in a complete way, allowing high speed in the exploration and analysis.

In continuity, Digital TWIN: will allow us to make predictive analyzes, that is, based on historical data, analyze statistically to simulate or predict machine behavior. IOT or Internet of Things: will connect this information generating autonomous decisions for the machines. 3D printing or additive manufacturing: recreates three-dimensional copy of products and prototypes, enabling the production of impossible products in conventional processes. The interviewee when defining IOT and its benefits to the company agrees with that says that in a survey conducted in 2016 by Gartner, it says that the internet of things will make many companies more efficient and more competitive, using it to improve their operations and also create new businesses, that is, the autonomous decisions of the machines will bring efficiency and improvements to the company.

\section{THEORETICAL DISCUSSION}

\section{Industry and the advent of the fourth industrial revolution}

With the industrial revolution, the industry started looking for better ways to solve production problems and improve the performance of its actions. All that searching for agile solutions raised and still raises the development and growth of the use of many technologies in all areas of production. It is possible to highlight some solutions and technologies used by the industry and which represented a new way that organized the production system, effectively increasing productivity and performance results, becoming a mark of great relevance in industrial evolution.

Thus identified the "eras" of the industry, three are known: first: use of steam engines as a propellant of industry, from the $17^{\text {th }}$ century. Second: use of electricity, late $19^{\text {th }}$ century. Third: Automation, from the $20^{\text {th }}$ century (SUGAYAMA et al., 2016). Still on how to characterize the phases of each of the industrial revolutions Amorim (2017) complementarily says it can be understood as: $4^{\text {th }}$ Industrial Revolution (present and future) basically decentralized industrial processes, controlled by "cyber-physical" systems and by the "internet of things"; $1^{\text {st }}$ Industrial Revolution (1780-1870), emergence of the steam engine; $2^{\text {nd }}$ Industrial 
4.0 Industry: understanding the impact of technological changes of the fourth industrial revolution on competitiveness in sandal factories of Cariri Region

BARRETO, A. V. R.; SANTOS, A. W.; GOMES FILHO, A. W.

Revolution (1870 - 1970), use of electricity, petroleum-derived fuels and steel; $3^{\text {rd }}$ Industrial Revolution (1970 - Present day), caused by the advance of electronics, computer systems and robotics.

Although, other authors perceive this moment of industry as the beginning of the fourth industrial revolution. According to Amorim (2017) 4.0 industry is the concept that is used to identify the $4^{\text {th }}$ industrial revolution, where the lines to characterize this concept are the main current technological innovations, control of information and automation technologies. Morais et al. (2016) complement showing that 4.0 industry can also be seen as a set of innovations that bring with them transitional impacts to its implementation and custom in its use, where the system and all its operations undergo great transformations and change completely its concepts.

Agreeing and complementing what Amorim (2017) says above, Sugayama et al. (2016) mention that the concept of 4.0 industry represents a new era for the industry. That would then be identified by the use of intelligent and technological industrial systems, that will make automatic production decisions, in complex data handling and manipulation structures. These data will be created from the interconnection of the means of production with its products, as well as the connection to the internal and external environment of the industry, and also to the final customer.

\section{Technological changes, from automation to smart factories (internet of things, Big Data e cyber physical system)}

As clarified in the subject discussed earlier, the industrial revolution brought several technological changes and integration of some of them, thus characterizing 4.0 industry, with this it is necessary that these technological changes that characterize and are recognized as the 4.0 industry's era can be better understood and explained for the clarification on that subject. The changes that have arisen in today's society, resulting from the globalization of the economy, the development of communication technologies and also information, caused transformations in different spheres, such as: economic, social and cultural, bringing with it new challenges for companies, the labour market in general, and several other areas (CASTRO, 2005).

To contextualize and discuss about these technologies that are identified as part of the 4.0 industry the 'Internet of Things, big data e cyber physical system', are expressions that best characterize the changes of the fourth revolution, and thus can be seen as of great relevance, identifying through its definitions and actions the evolution that is currently happening around us.

IOT: Internet of Things is seen as the evolution of the simple internet, the internet of things promises to revolutionize in several areas, being able to interconnect objects through networks, whether they are from internet or not, transmitting and sharing important information, which will cause companies to streamline many of its processes, reducing or even ending manual labor in some of its areas (EVANS, 2011).

That complements Evans, the internet of things connects everyday electronic devices to industrial machines and also means of transportation connected to the internet network. Through a survey conducted in 2016 by Gartner, she says that the internet of things will make many companies more efficient and more competitive, using for the improvement of its operations and also creating new businesses. 
4.0 Industry: understanding the impact of technological changes of the fourth industrial revolution on competitiveness in sandal factories of Cariri

Introducing also the Big Data, according to Borba et al. (2013) the Big Data tracks the navigation of Internet users searching for information about their interests, building databases for companies to use in their favor and sell their products according to what the customer is looking for. But according to Vieira et al. (2012) the big data may still be a broad term and without common consensus, identified as the efficient processing of large volumes of complex data for various applications. Complementing what Vieira says, Davenport (2013) identifies the big data as a term describing large volumes of data, which may be structured or unstructured, and may be used as a strategy for the company's competitive advantage. One important caveat of Davenport on the big date is as follows

It is important to remember that the main value of big data does not come from data in its raw form, but from the processing and analysis of these data and the insights, products and services that emerge from this analysis. The radical changes in the technologies and big data management approaches must be accompanied, similarly, by dramatic changes in how data supports decisions and generate innovation in products and services. (DAVENPORT, 2013)

And finally bringing the Cyber Physical System, can be seen as an ally to assist the internet of things being able to enhance its capacity according to how it is used, as well as the internet of things, cyber physical systems are designed to support applications that can manage large amounts of data and also a greater variety of environment data (ZANNI, 2015). Another definition given by Frazzon et al. (2015) the physical cyber systems integrate the execution of physical processes, with software and communication tools, providing design techniques and data analysis in integrated scale, communication between computers, networks and physical systems, interact in such a way as to require new technologies, always allying cybernetic systems with physical systems, in a direct man-machine relationship.

According to Silveira et al. (2003) "automation is a set of techniques designed to make automatic the accomplishment of tasks". Ribeiro (1999) speaks a bit more by saying that "Automation is the replacement of human or animal labor by machine. Automation is a machine or system automatically operation or by remote control, with minimal interference from the human operator". Groover (2011 cited by SCHRÖDER et al., 2015) complements citing that

[...] a company has nine reasons to seek automation in your productive system. They are: increasing productivity; reduce labor costs; minimize the effects of lack of workers; reduce or eliminate manual routines and administrative tasks; increase worker safety; improve the quality of the product; decrease the production time; perform processes that cannot be performed manually and avoid the high cost of non-automation.

All this makes up a sort of ideal plan for the best possible operation of any company or organization, encouraging them to be efficient and to always achieve their best, thus arising the big possibility that in the future factories may be on a level of quality, and automation never seen before. In far less time than you might imagine the technology will advance to the point of interconnect through internet networks machines, raw materials and workers, making them communicate in real time. Will then be the apex of automation, where everything will be controlled from afar, by digital means, a smart factory in a real environment, all controlled from a distance and in real time (RODRIGUES et al., 2016).

The vision of Rodrigues et al. (2016) is very realistic and possibly will be seen in companies very soon, the trend of all the advances brought by 4.0 industry and current technological innovations is actually turn 
4.0 Industry: understanding the impact of technological changes of the fourth industrial revolution on competitiveness in sandal factories of Cariri Region

BARRETO, A. V. R.; SANTOS, A. W.; GOMES FILHO, A. W.

the factories into smart factories, benefiting companies and the market in which it is inserted, producing with greater speed, quality and efficiency, with the lowest cost benefit and less use of manual labor as well.

\section{Competitive Advantage}

One of the simplest definitions of Competitive Advantage is that it is the state that modifies or differentiates one company or professional from another, a competitive advantage arises from a core competence of the company, and this competence becomes a differential skill in the segment where the company operates, but to be truly a competitive advantage, you must run and make better use of this differential than the other competitors (MENDES, 2011).

Therefore, technological changes and new technologies can become a differential in the market, becoming a competitive advantage for a company. With the current business reality in the country and in the world, where more and more companies are active, it is necessary to achieve a differential to conquer potential customers, and that can be through investment in technology and new ways of acting, by drawing an innovative strategy plan, seeking to become unique among competitors.

Oliveira (2009) explains that for the structuring of strategic scenarios in the company it is necessary an analysis of these scenarios and competitors, which will serve as future measures for the growth of the company, thus establishing the organization's strengths as a competitive advantage based on established strategies.

Automating factories through the use of technologies that reduce manual labor creates a competitive advantage over competitors when it is used to its maximum capacity, maintaining the growth, development, and quality of what is produced, can also refine and improve more and more in relation to its processes. Goldratt et al. (1992) who by this time had a futuristic view on the subject, says that many companies are in the race to try to make their factories fully automated, even with large investments and running some risks, see it as something that you invest now to have the return in the future, without falling behind in this great race in search of differential and competitive advantage.

\section{CONCLUSIONS}

At the end of the research was notorious the great difference in which companies and their managers receive and perceive the changes that the fourth industrial revolution with the 4.0 industry has brought to their work environment, it was noticed that according to the size of the company, the degree of knowledge about the subject changes and goes from one extreme to another, the choice of companies being one small, one medium and one big was not in vain, because in this way we can truly perceive that the realities of each one puts them at completely different levels in relation to the knowledge of their managers, and the real need of this knowledge for the better progress of the company.

It was possible to notice that according to the size of the companies the level of education of its managers evolved from the smallest to the largest, where the small company had a manager with minimal 
4.0 Industry: understanding the impact of technological changes of the fourth industrial revolution on competitiveness in sandal factories of Cariri Region

training, only the high school and a technical education, the manager of the mid-sized company had a higher level of education with a college degree, and the manager of the large company had training, graduation and specialization, seeking even more knowledge over time.

Regarding the percentage of automation of each of them, it was possible to notice that it also evolved from the smallest to the largest, where the small business had $30 \%$, the medium-sized $40 \%$ and the big-sized $50 \%$, realizing that each of them does only what is within their reach and within their possibilities, and that in a way the small and medium-sized companies are walking slowly, compared to the big one, since it is the only one that seeks the 4.0 standard and set goals to reach this level, the investment in machines, systems, infrastructure and new technologies in general are much more present in the big company, where it seeks to prepare its employees to evolve with the company.

It was concluded at the end of the research that the reality of each manager and company is totally related to the way they receive and use the technologies of the fourth industrial revolution, the lack of knowledge hinders the perception of exploitation and correct application of strategies to obtain advantages, and the lack of resources and structure of smaller firms means that the potential use of these technologies to gain competitive advantage is not so much used by their managers.

I leave then the suggestion for a new research and construction of article to be carried out in the large company that was studied, as quoted in the paper, of the 3 factories, the big one was the only one where specific strategies and targets were found so that it could reach 4.0 industry level, so it would be extremely important a study where you can know and clarify the steps that a company must follow to reach the level of 4.0 industry.

\section{REFERENCES}

AMORIM, J. E.. The "Industry 4.0" and the sustainability of the model of financing of the General Social Security System. Caderno de Direito Actual, n.5, 2017.

BORBA, D. K.; SANTOS, L. F. A.; KAWAMOTO JÚNIOR, L. T.. Big Data: percepção dos usuários sobre vantagens e invasão de privacidade. São Paulo: 2013.

CASTRO, A. M. D. A.. Mudanças Tecnológicas e suas Implicações na Política de Formação do Professor. Rio de Janeiro: 2005.

DAVENPORT, T. H.. Big Data em Grandes Empresas. São Paulo: 2013.

EVANS, D.. A Internet das Coisas: Como a próxima evolução da Internet está mudando tudo. San José: Cisco IBGS, 2011.

FRAZZON, E. M.; SILVA, L. S.; HURTADO, P. A.; BORGES, H. F.. Aplicação do Conceito de Cyber-Physical Systems em Manufacturing Execution System. In: ENCONTRO NACIONAL DE ENGENHARIA DE PRODUÇÃO, 35. Anais. Fortaleza: 2015.

GERHARDT, T. E.; SILVEIRA, D. T.. Métodos de pesquisa. Porto Alegre: EDUFRGS, 2009.
GOLDRATT, E. M.; FOX, R. E.. A corrida pela vantagem competitiva. São Paulo: Claudiney Fullmann, 1992.

GROOVER, M. P.. Automação industrial e sistemas de manufatura. 3 ed. São Paulo: Pearson Prentice Hall, 2011.

MENDES, J.. O que são vantagens competitivas?. João Pessoa: 2011.

MORAIS, R. R.; MONTEIRO, R.. A indústria 4.0 e o impacto na área de operações: Um ensaio. In: SIMPÓsIO INTERNACIONAL DE GESTÃO DE PROJETOS, 5. Anais. São Paulo: 2016.

OLIVEIRA, D. P. R.. Estratégia empresarial e vantagem competitiva: como estabelecer, implementar e avaliar. 6 ed. São Paulo: Atlas, 2009.

RIBEIRO, M. A.. Automação Industrial. 4 ed. Salvador: 1999. RODRIGUES, L. F.; JESUS, R. A.; SHUTZER, K.. Industrie 4.0: Uma revisão de literatura. Revista de Ciência e Tecnologia, v.19, n.38, 2016.

SEVERINO, A. J.. Metodologia do trabalho científico. 23 ed. São Paulo: Cortez, 2007. 
4.0 Industry: understanding the impact of technological changes of the fourth industrial revolution on competitiveness in sandal factories of Cariri Region

SILVIRA, L.; LIMA, W. Q.. Um breve histórico conceitual da Automação Industrial e Redes para Automação Industrial. Natal: UFRN, 2003.

\section{SILVEIRA, C. B.. O Que é Indústria 4.0 e Como Ela Vai} Impactar o Mundo. Sorocaba: 2016.

SUGAYAMA, R.; NEGRELLI, E.. Connected vehicle on the way of Industry 4.0. Monografia (Pós-Graduação em Engenharia Automotiva) - Curitiba: Universidade Tecnológica Federal do Paraná, 2016.
VERGARA, S. C.. Projetos e relatórios de pesquisa em administração. 11 ed. São Paulo: Atlas, 2009.

VIEIRA, M. R.; FIGUEIREDO, J. M.; LIBERATTI, G.; VIEBRANTZ, A. F. M.. Bancos de Dados NoSQL: Conceitos, Ferramentas, Linguagens e Estudos de Casos no Contexto de Big Data. In: SIMPÓSIO BRASILEIRO DE BANCOS DE DADOS. Anais. Fortaleza: 2012.

ZANNI, A.. Sistemas cyber-físicos e cidades inteligentes. Armonk: IBM, 2015.

A CBPC - Companhia Brasileira de Produção Científica (CNPJ: 11.221.422/0001-03) detém os direitos materiais desta publicação. Os direitos referem-se à publicação do trabalho em qualquer parte do mundo, incluindo os direitos às renovações, expansões e disseminações da contribuição, bem como outros direitos subsidiários. Todos os trabalhos publicados eletronicamente poderão posteriormente ser publicados em coletâneas impressas sob coordenação da Sustenere Publishing, da Companhia Brasileira de Produção Científica e seus parceiros autorizados. Os (as) autores (as) preservam os direitos autorais, mas não têm permissão para a publicação da contribuição em outro meio, impresso ou digital, em português ou em tradução. 